\title{
Bimbingan Agama Terhadap Tindak Kriminal (Preman)
}

\author{
Abdul Khahar \\ Dosen Sekolah Tinggi Agama Islam Negeri Mandailing Natal
}

\begin{abstract}
The gap between religious norms or teachings and daily behavior is a sign of a multidimensional crisis. One impact is the increasingly widespread crime that occurred in the midst of society, both successfully covered by print and electronic media or other unpublished crimes. Crime is not a hereditary event (inherited from birth, inheritance), nor is biologically inherited. Criminal behavior that can be done by women or men, can take place at any age of children, adults or elderly. Crimes can be committed consciously that is fully considered, planned and directed at one specific purpose in a truly conscious manner. Also, it can be done semi-consciously, for example driven by intense impulses, wracked by very strong coercive impulses (compulsions), and by strong obsessions. Crimes can be done unconsciously at all, for example forced to defend his life, someone must react fighting even forced to strike back. Modern societies with middle to upper economic levels often foster high material aspirations and are often accompanied by unhealthy social ambitions.
\end{abstract}

Keyword: Gangster, Criminal Act, Religious Guidance.

\section{Pendahuluan}

Masyarakat modern yang serba kompleks, sebagai produk dari kemajuan teknologi, mekanisasi dan urbanisasi memunculkan banyak masalah sosial. Adaptasi atau penyesuaian diri terhadap masyarakat modern yang hyper kompleks itu menjadi tidak mudah. Kesulitan menghadapi adaptasi adjustment menyebabkan kebingungan, kecemasan dan konflik-konflik, baik yang terbuka dan eksternal sifatnya, maupun yang tersembunyi dan internal dalam batin sendiri. Hal tersebut mendorong orang untuk mengembangkan pola tingkah laku menyimpang dari norma-norma 
umum, termasuk di dalamnya norma-norma agama dengan berbuat semau sendiri demi kepentingan sendiri dan mengganggu atau merugikan orang lain. Jika kita menatap kenyataan perilaku sosial yang mayoritas beragama Islam, masih ada persoalan besar. Kehebatan ajaran agama Islam, terutama dalam landasan moral masyarakat atau etika sosial, memang tidak diragukan lagi, namun banyak nilai-nilai tadi yang tidak terwujud dalam kehidupan sehari-hari atau dalam sistem sosial. ${ }^{1}$

Dambaan pemenuhan kebutuhan yang melimpah-limpah, misalnya untuk memperoleh harta kekayaan dan barang-barang mewah, tanpa memiliki kemampuan untuk mencapainya dengan jalan yang wajar, mendorong individu untuk melakukan tindak kriminal. Dengan kata lain bisa dikatakan: jika terdapat ketidaksesuaian atau pertentangan antara keiginan dengan kemampuan pribadi, maka peristiwa sedemikian ini mendorang orang untuk melakukan tindak kriminal. Atau jika terdapat diskrepansi antara aspirasi-asperasi dengan potensi-potensi maka akan terjadi ketidakmampuan untuk menyesuaiakan secara ekonomis, yang mendorong orang untuk bertindak jahat atau melakukan tindak pidana. Tingkah laku kriminal itu merupakan produk dari pertumbuhan sosial, juga deferensiasi dari sivilisasi atau pembudayaan industri yang modern dan hyper kompleks. Pada zaman modern sekarang ini banyak tingkah laku kriminal yang tidak lagi dianggap sebagai perbuatan anti sosial atau kriminal. Perbuatan-perbuatan korup, memberi hadiah-hadiah guna memudahkan penyelesaian masalah, pemberian "bulu bekti" (tanda bakti) kepada pimpinan guna menutup perbuatan kriminal. Juga penjualan minum-minuman keras dan bahan-bahan yang mengandung racun memabukkan, misalnya ganja, sekalipun oleh masyarakat dianggap bukan kejahatan, namun oleh semua golongan masyarakat, perbuatan tersebut dianggap sebagai perbuatan anti sosial. $^{2}$

\footnotetext{
${ }^{1}$ Qodri Azizy, Pendidikan Agama Untuk Membangun Etika Sosial (Semarang: Aneka Ilmu, 2002), 82.

${ }^{2}$ Kartini Kartono, Patologi Sosial Jilid I (Jakarta: Rajawali Pers, 2011), 155.
} 
Kalau ditelusuri lebih jauh mengenai semakin maraknya tindak kriminalitas, sebenarnya keluarga juga memberikan pengaruh yang sangat menentukan pada pembentukan watak dan kepribadian seseorang. Keluarga merupakan unit sosial terkecil yang memberikan stempel dan pondasi primer bagi perkembangan seseorang. Selanjutnya lingkungan ikut menentukan nuansa tingkah laku dan kepribadian. Baik buruknya struktur keluarga dan masyarakat memberikan efek yang baik atau yang buruk pada pertumbuhan seseorang. ${ }^{3}$ Untuk menanggulangi dan mengantisipasi semakin meningkatnya tindak kriminalitas dibutuhkan adanya undang-undang hukum pidana, agama juga bisa digunakan sebagai alat yang efektif. Sebab salah satu fungsi sosial dari agama adalah memberi sanksi kepada sejumlah besar tata kelakuan. Dalam konteks ini agama memberikan peran penting dalam pengendalian sosial. Ini terlaksana melalui pengertian tentang baik dan jahat. Agama memberi contoh perilaku-perilaku yang baik dan jahat serta menanamkan doktrin bahwasanya setiap perilaku yang baik atau buruk mengandung konsekwensi baik di dunia ataupun di akherat mengenai surga dan neraka. Nilai-nilai ini sangat dipercayai oleh masyarakat beragama. ${ }^{4}$

\section{Motivasi Tindak Kriminal}

Tim Penyusun Kamus Besar Bahasa Indonesia mendefinisikan bahwa motivasi adalah (1) Dorongan yang timbul pada diri seseorang sadar atau tidak sadar untuk melakukan suatu tindakan dengan tujuan tertentu. (2) Usaha-usaha yang dapat menyebabkan seseorang atau kelompok orang tertentu bergerak untuk melakukan sesuatu karena ingin mencapai tujuan yang

\footnotetext{
${ }^{3}$ Kartini Kartono, Psikologi Anak; Psikologi Perkembangan (Bandung, Mandar Maju, 1995), 224.

${ }^{4}$ Soekadijo, Reg., Antropologi Jilid 2 (Jakarta: tp, 1985), 214.
} 
dikehendaki atau mendapat kepuasan dengan perbuatannya. ${ }^{5}$ Bernard Berelson dan Gary A. Stener dalam Machrony mendefinisikan motivasi sebagai all those inner striving conditions variously described as wishes, desires, needs, drives, and the like. Motivasi dapat diartikan sebagai keadaan kejiwaan dan sikap mental manusia yang memberikan energi, mendorong kegiatan (moves), dan mengarah atau menyalurkan periuk kearah mencapai kebutuhan yang memberi kepuasan atau mengurangi ketidakseimbangan. ${ }^{6}$ Motivasi menurut Robert Epstein adalah pernyataan dari dalam berupa gerak yang sering muncul, sebelum dalam melakukan tingkah laku. ${ }^{7}$ Sedangkan menurut Martin Handoko motivasi adalah suatu tenaga atau faktor yang terdapat di dalam diri manusia, yang menimbulkan, mengarahkan dan mengorganisasikan tingkah lakunya. Peranan motivasi pada tingkah laku manusia sangatlah besar, hal tersebut terbukti bahwa manusia sebagai penggerak tingkah laku manusia, karena setiap tindakan manusia digerakkan dan dilatarbelakangi oleh motif tertentu. Tanpa termotivasi orang tidak akan berbuat apa-apa. ${ }^{8}$ Dari pengertianpengertian tersebut penulis dapat menarik kesimpulan bahwa motivasi adalah sebagai dorongan yang timbul pada diri seseorang secara sadar maupun tidak sadar untuk melakukan kegiatan (moves) karena ingin mencapai tujuan yang dikehendakinya atau mendapat kepuasan dengan perbuatannya.

Kriminal berasal dari kata crime yang artinya kejahatan bisa disebut kriminalitas karena ia menunjukkan suatu perbuatan atau tingkah laku kejahatan, seperti dikatakan oleh S. Wojowasito, W. J.S. Poerwadarminta bahwa crime adalah kejahatan dan kriminal dapat diartikan jahat atau penjahat, maka kiminalitas dapat

${ }^{5}$ Departemen Pendidikan dan Kebudayaan, Kamus Besar Babasa Indonesia (Jakarta: Balai Pustaka, 1997), 1225.

${ }^{6}$ Siswanto, Pengantar Manejemen (Jakarta: Bumi Aksara, 2005), 119.

${ }^{7}$ Robert Epistein, Memotivasi (Yogyakarta: Pustaka, 2004), 2.

${ }^{8}$ Martin Handoko, Motivasi Daya Penggerak. (Yogyakarta: Kanisius, 1992), 9. 
diartikan perbuatan kejahatan. ${ }^{9}$ Kriminal dalam Kamus Besar Bahasa Indonesia adalah hal-hal yang bersangkutan dengan kejahatan (pelanggar hukum) yang dapat dihukum oleh undangundang pidana. Para Ilmuan menegaskan bahwa Crime adalah berbagai tindakan yang jelas-jelas melanggar hukum. ${ }^{10}$ Dari pengertian di atas dapat ditarik kesimpulan bahwa kriminal adalah menunjukkan suatu perbuatan atau tingkah laku kejahatan yang melanggar hukum dan dapat dihukum dengan undang-undang pidana.

Kriminalitas merupakan perilaku manusia ditinjau dari aspek sosial, yaitu suatu tindak kejahatan yang bisa dilakukan oleh siapa pun baik secara sengaja (sadar dan terencana) serta diarahkan pada maksud tertentu, ataupun setengah sadar; misalnya didorong oleh impuls-impuls yang begitu hebat, seperti himpitan ekonomi. Bahkan kriminilatas juga bias dilakukan tanpa kesadaran sama sekali. Misalnya karena terpaksa untuk mempertahankan hidupnya, seseorang harus melawan dan terpaksa membalas menyerang, sehingga terjadi peristiwa pembunuhan. ${ }^{11}$

Di samping itu, kriminalitas ini pada umumnya adalah akibat dari kegagalan sistem pengontrol diri, yaitu gagal dalam mengawasi dan mengatur perbuatan instintif mereka. Jadi, merupakan produk ketidakmampuan anak remaja dalam mengendalikan emosi primitive mereka, yang kemudian disalurkan dalam perbuatan jahat. $^{12}$ Dengan demikian pengertian motivasi tindak kriminal adalah suatu dorongan yang timbul dari diri seseorang untuk melakukan sesuatu perbuatan atau tingkah laku yang melanggar norma-norma yang berlaku. Motivasi merupakan kecenderungan yang timbul pada diri seseorang secara

\footnotetext{
${ }^{9}$ Abdul Syani, Sosiologi Kriminalitas (Bandung: CV. Remaja Karya, 1987), 20.

${ }^{10}$ Adam Kuper dan Jessica Kuper, Ensiklopedi Ilmu-ilmu Sosial, Edisi 2 (Jakarta, PT. Grafindo Persada, 2000).

${ }^{11}$ Kartini Kartono, Patologi Sosial, 121.

${ }^{12}$ Thomas F. Odea, Sosiologi Agama; Suatu Pengenalan Awal (Jakarta: Rajawali Press, 1985), 5.
} 
sadar atau tidak sadar melakukan tindakan dengan tujuan tertentu atau usaha-usaha yang menyebabkan seseorang atau kelompok tergerak melakukan sesuatu karena ingin mencapai tujuan yang dikehendaki. $^{13}$

Tindak Kriminal secara yuridis formal adalah bentuk tingkah laku yang bertentangan dengan moral kemanusiaan (immoral), merugikan masyarakat, asusila, sifatnya dan melanggar hukum serta undang-undang pidana. Yuridis formal di sini disandarkan pada KUHP (Kitab Undang-undang Hukum Pidana) yang mengatur hal-hal yang berkenaan dengan tindak pidana. Adapun pasalpasal yang penulis jadikan acuan dalam mendefinisikan tindak kriminal yang dilakukan oleh anggota Kipas antara lain pasal 153181 yang memuat mengenai pelanggaran terhadap ketertiban umum, antara lain: secara terbuka dan di muka umum menghasut serta menyatakan rasa permusuhan, kebencian dan hinaan kepada pemerintah, dengan kekerasan mengancam dan berusaha merobohkan serta melanggar pemerintahan yang sah, tidak melakukan tugas kewajiban jabatannya, menjadi anggota organisasi terlarang menurut hukum, melakukan keonaran, huru-hara dan menganggu ketentraman umum. Juga pada pasal 187-206 yang berisi tentang kejahatan yang membahayakan keamanan umum dan barang, antara lain: mengakibatkan kebakaran peletusan dan banjir, merusak bangunan-bangunan listrik untuk umum, mendatangkan bahaya maut kepada orang, merusak bangunan dan jalan-jalan umum, dengan sengaja mendatangkan bahaya bagi lalu lintas umum dan pelayaran, meracuni sumur dan sumber mata air minum untuk keperluan umum. ${ }^{14}$

Dari pemaparan mengenai definisi di atas penulis dapat menyimpulkan bahwa motivasi tindak kriminal adalah suatu dorongan yang timbul dari diri seseorang untuk melakukan suatu perbuatan atau tingkah laku yang melanggar norma-norma yang

${ }^{13}$ EM Zul Fajri dan Ratu Aprilia Senja, Kamus Lengkap Bahasa Indonesia Edisi Revisi (Cet. 2; Semarang: Difa Publishers, 2007), 575.

${ }^{14}$ Kartini Kartono, Patologi Sosial, 127. 
berlaku pada suatu masyarakat atau menentang hukum negara. Kejahatan remaja yang merupakan gejala penyimpangan dan patologis secara sosial itu juga dapat dikelompokkan dalam satu kelas defektif secara sosial dan mempunyai sebab musabab yang majemuk, jadi sifatnya multi kausal. Para sarjana mengolongkan beberapa kategori teori sebagai berikut:

1. Teori Biologis

Tingkah laku sosiopatik atau Dilenkuen pada anak-anak dan remaja dapat muncul karena faktor-faktor fisiologis dan struktur jasmaniyah seseorang, juga dapat juga cacat jasmaniyah yang dibawa sejak lahir. Kejadian ini berlangsung.

a. Melalui Gen atau plasma pembawa sifat dalam keturunan, atau melalui kombinasi Gen dapat juga disebabkan oleh tidak adanya Gen tertentu, yang semua bisa memunculkan penyimpangan tingkah laku, dan anak-anak menjadi dilenkuen secara potensial.

b. Melalui pewarisan tipe-tipe kecenderungan yang luar biasa (abnormal), sehingga membuahkan tingkah laku dilenkuen. Melalui Pewarisan kelemahan konstitusional jasmaniyah tertentu yang menimbulkan tingkah laku dilenkuen atau sosiopatik. Misalnya cacat jasmaniyah bawaan seperti halnya berjari-jari pendek dan penyakit gula itu erat berkolerasi dangan sifat-sifat kriminal serta penyakit mental.

2. Teori Psikogenis (Psikologis dan Psikiatris)

Teori ini menekankan sebab-sebab tingkah laku dilenkuen anak-anak dari aspek psikologis atau isi kejiwaan antara lain faktor intelegensi, fantasi, rasionalisasi, internalisasi diri yang keliru, konflik batin, emosi yang kontroversial, kecenderungan psikopatologis.

3. Teori sosiogenis

Para sosiolog berpendapat penyebab tingkah laku dilenkuen pada anak remaja adalah murni sosiologi atau sosial psikologis sifatnya. Misalnya oleh pengaruh struktur sosial yang deviatif, tekanan kelompok, peranan sosial, status sosial atau internalisasi 
simbolis yang keliru. Maka faktor-faktor kultural dan sosial itu sangat mempengaruhi, bahkan mendominasi struktur lembagalembaga sosial dan peranan sosial setiap individu ditengah masyarakat, status individu ditengah kelompoknya partisipasi sosial. Jadi sebab-sebab kejahatan anak remaja itu tidak hanya terletak pada lingkungan familial dan tetangga saja akan tetapi terutama sekali, disebabkan oleh kelompok kulturalnya.

4. Teori Subkultur

Adapun sebab-sebanya: a. Bertambahnya dengan cepat jumlah kejahatan, dan meningkatnya kualitas kekerasan serta kekejaman yang dilakukan oleh anak-anak remaja yang dimiliki subkultural dilenkuen. b. Meningkatnya jumlah kriminalitas mengakibatkan sangat besarnya kerugian dan kerusakan secara universal, terutama terdapat di negara-negara industri yang sudah maju, disebabkan oleh meluasnya kejahatan remaja. Perilaku menyimpang adalah tingkah laku yang dinilai sebagai penyimpangan dari aturan-aturan normatif atau yang dinilai sebagai penyimpangan dari pengharapan-pengharapan sosial. Dalam ilmu sosiologi maupun psikologi sosial perilaku menyimpang jarang sekali didefinisikan dalam arti biologis dan psikopatologis. Sering kali ada asumsi bahwa gejala-gejala penyakit jiwa dapat digolongkan perilaku menyimpang. ${ }^{15}$ Bentuk-bentuk Kriminal. Salah satu kesukaran terbesar dari pada kriminal adalah cara bagaimana harus membagi-bagi jenis kejahatan. Pembagian yang terkenal adalah kejahatan terhadap agama, terhadap orang, terhadap milik. Pembagian kejahatan menurut bentuknya:

a. Perampok dan gengsterisme, yang sering melakukan operasinya bersama-sama dengan organisasi-organisasi legal.

b. Penipuan-penipuan, permainan-permainan dalam bentuk judi dan perantara-perantara "kepercayaan", pemerasan (blackmailing), ancaman untuk mempublisir skandal dan

\footnotetext{
${ }^{15}$ Kartini Kartono, Patologi Sosial, 21-25.
} 
perbuatan manipulatif.

c. Pencurian dan pelanggaran, perbuatan kekerasan, perkosaan, pembegalan, penjambretan atau pencopetan, perampokan, pelanggaran lalu lintas, ekonomi, pajak, dan bea cukai. ${ }^{16}$

\section{Urgensi dan Metode Bimbingan Agama Kepada Pengamen}

Pengamen berasal dari kata dasar "amen" yang memiliki makna mengamen menyanyi dan bermain musik berkeliling (dengan mengharapkan pemberian uang secara suka rela). Sedangkan Pengamen adalah orang yang kerjanya sebagai penyanyi keliling; seniman jalanan. ${ }^{17}$ Amen adalah kata dasar dari pengamen yang memiliki makna mengamen menyanyi dan bermain musik berkeliling (dengan mengharapkan pemberian uang secara suka rela). ${ }^{18}$ Marco Marnadi sebagai salah satu anggota Kipas mengartikan pengamen adalah orang yang aktivitasnya menyanyikan satu lagu atau beberapa lagu yang berada baik di dalam bus, di rumah-rumah, di warung, maupun pasar, dengan maksud untuk menerima imbalan dari orang lain seikhlasnya tanpa ada paksaan. Selain itu dalam menyanyi tidak diadakan di atas panggung atau suatu konser di mana penontonnya lebih dari 50 orang. Pengertian tersebut penulis menyimpulkan bahwa pengamen adalah orang yang pekerjaanya menyanyi baik karena hobi atau faktor ekonomi yang bertujuan untuk mendapatkan imbalan uang.

Bimbingan adalah proses pelayanan yang pada individuindividu guna membantu mereka memperoleh pengetahuan dan ketrampilan yang diperlukan dalam membuat pilihan-pilihan, rencana-rencana dan interpretasi yang diperlukan untuk penyesuaian diri yang baik. Bimbingan adalah bantuan yang diberikan oleh seorang laki-laki atau perempuan, yang memiliki kepribadian yang memadahi dan terlatih dengan baik kepada

\footnotetext{
${ }^{16}$ Kartini Kartono, Patologi Sosial, 129-130.

${ }^{17}$ Em Zul Fajri, Kamus Lengkap Bahasa Indonesia (Jakarta: Difa Publiser, 2007), 51.

${ }^{18}$ Departemen Pendidikan dan Kebudayaan, Kamus Besar Babasa Indonesia, 57.
} 
individu setiap usia untuk membantunya mengatur kegiatan hidupnya sendiri, mengembangkan pandangan hidupnya sendiri, membuat keputusan sendiri, dan menanggung bebannya sendiri. ${ }^{19}$

Menurut Ainur Rahim Faqih, bimbingan Islam adalah proses pemberian bantuan terhadap individu agar mampu hidup selaras dengan ketentuan dan petunjuk Allah, sehingga dapat mencapai kebahagiaan hidup di dunia dan akhirat. ${ }^{20}$ Dengan demikian bimbingan Islami merupakan proses bimbingan sebagaimana kegiatan ajaran agama Islam, artinya berlandaskan al-Qur'an dan Sunnah Rasul. Dari pengertian tersebut, bimbingan mengalami suatu perkembangan yang cukup berarti dari masa ke masa, yaitu dari hanya sekedar mempersiapkan seseorang untuk memasuki dari suatu jabatan/kerjaan tertentu sampai kepada pemberian bantuan dalam pengentasan masalah-masalah pendidikan, sosial dan pribadi. Dengan demikian pelayanan bimbingan telah menjangkau berbagai aspek yang lebih luas dari perkembangan dan kehidupan manusia. Adapun unsur-unsur pokok dari bimbingan sebagai berikut:

1. Pelayanan bimbingan merupakan suatu proses. Ini berarti bahwa pelayanan bimbingan bukan sesuatu yang sekali jadi, melainkan melalui lika-liku tertentu sesuai dengan dinamika yang terjadi di dalam pelayanan itu.

2. Bimbingan merupakan proses pemberian bantuan. "Bantuan" di sini tidak diartikan sebagai bantuan materil (seperti uang, hadiah, sumbangan dan lain-lain), melainkan bantuan yang bersifat menunjang bagi pengembangan pribadi individu yang dibimbing.

3. Pemecahan masalah dalam bimbingan dilakukan oleh dan atas kekuatan klien sendiri. Dalam hal ini bimbingan adalah memperkembangkan kemampuan klien untuk dapat mengatasi

${ }^{19}$ H. Prayitno dan Erman Amti, Dasar-dasar Bimbingan dan Konseling (Jakarta: PT. Rineka Cipta,

1999), 94.

${ }^{20}$ Ainur Rahim Faqih, Bimbingan Konseling Islam (Yogyakarta, UII Press, 2001), 2. 
sendiri masalah-masalah yang dihadapinya, dan akhirnya dapat mencapai kemandirian.

4. Bimbingan tidak hanya diberikan untuk kelompok-kelompok umur tertentu melainkan semua umur. ${ }^{21}$

Berdasarkan beberapa pengertian bimbingan tersebut maka dapat ditarik kesimpulan bahwa bimbingan adalah proses pemberian bantuan yang dilakukan oleh orang yang ahli kepada orang/beberapa orang individu baik anak-anak, remaja, maupun dewasa, agar orang yang dibimbing dapat mengembangkan kemampuan dirinya sendiri dan mandiri; dengan memanfaatkan kekuatan individu dan sasaran yang ada dan dapat dikembangkan; berdasarkan norma-norma baik agama atau masyarakat yang berlaku. Agama dalam kamus besar bahasa Indonesia adalah segenap kepercayaan (kepada Tuhan serta dengan ajaran kebaktian dan kewajiban-kewajiban yang bertalian dengan kepercayaan itu). ${ }^{22}$ Secara terminologi atau istilah agama adalah peraturan Allah yang diturunkan kepada manusia dengan perantara rasulnya untuk menjadi pedoman dalam melaksanakan kehidupan dan penghidupan mereka dalam mencapai kejayaan hidup secara lahir maupun batin baik di dunia maupun di akhirat. $^{23}$

T.M. Hasbi Ashidieqy mengemukakan bahwa agama adalah suatu kumpulan peraturan yang ditetapkan untuk menarik dan menuntun para umatnya yang berakal kuat, yang suka tunduk dan patuh kepada kebaikan, supaya mereka memperoleh kebahagiaan dunia dan kesentosaan di akhirat, negeri yang abadi. Supaya dapat mendiami surga Jannatul Khulud, mengecap kelezatan dan tidak ada tolak bandingannya sera kekal selamanya). ${ }^{24}$ Islam adalah agama Allah SWT yang diturunkan

\footnotetext{
${ }^{21}$ Ibid

${ }^{22}$ Departemen Pendidikan dan Kebudayaan, Kamus Besar Bahasa Indonesia, 10.

${ }^{23}$ Syahminan Zaini, Wawasan Al-Qur'an Tentang Pembangunan Manusia Seutubnya (Malang: Kalam Mulia, 1986), 2.

${ }^{24}$ Hasbi Ashiddieqy, Al Islam Jilid 1 (Jakarta: Bulan Bintang, 1970), 27.
} 
kepada seluruh manusia melalui Rasul-Nya, sebagai agama yang universal, Islam menekankan pada amal perbuatan dalam tatanan sistem kehidupan, yang meliputi aqidah, politik, sosial, ekonomi dan segala aspek kehidupan manusia lainnya, karena Islam merupakan agama yang bertumpu pada kenyataan obyektif dalam kehidupan kesempurnaan dan kesungguhan ajaran Islam inilah sehingga ia tidak sekedar sebagai tuntunan hidup yang hanya untuk diketahui, dibicarakan, di dengarkan tanpa adanya pengamatan yang riil, akan tetapi untuk diamalkan dan dapat dikendalikan sikap, tindakan, perbuatan dan cara hidup yang Islami.

Supaya Islam tetap menjadi tuntunan hidup manusia, maka diperlukan adanya suatu kegiatan yang disebut dakwah. Menyampaikan kebenaran Islam sesuai dengan misinyasebagai agama yang Rahmat Lil'alamin. ${ }^{25}$ Dari pengertian-pengertian tersebut penulis simpulkan bahwa agama adalah suatu kepercayaan kepada Tuhan untuk menjalankan semua yang diperintah-Nya dan menjauhi apa yang dilarang-Nya Dari definisi di atas penulis dapat menarik kesimpulan bahwa bimbingan agama ialah proses pemberian bantuan dari seseorang ahli kepada seseorang guna membantu mereka untuk memperoleh pengetahuan agama.

Ada beberapa metode yang lazim digunakan dalam bimbingan keagamaan yang dalam hal ini adalah bimbingan agama Islam, di mana sasarannya adalah mereka yang berada dalam kesulitan, spiritual disebabkan faktor-faktor kejiwaan di dalam dirinya sendiri. Seperti tekanan batin, gangguan perasaan, dan tidak mampu berkonsentrasi. Menurut pendapat Arifin, ${ }^{26}$ dapat digunakan metode-metode sebagai berikut:

a. Metode Interview (Wawancara). Adalah salah satu cara memperoleh fakta-fakta kejiwaan yang dapat dijadikan pemecahan masalah.

\footnotetext{
${ }^{25}$ Amin, Mengatasi Krisis Setengah Baya (Bandung: Sinar Baru, 1997), 2.

${ }^{26}$ Arifin, Pokok-pokok Pikiran tentang Bimbingan dan Penyuluban Agama (Jakarta, Bulan Bintang, t.th), 52-55.
} 
b. Metode Kelompok (Group Guidance). Dengan menggunakan kelompok pembimbingan atau penyuluhan akan dapat mengembangkan sikap social

c. Metode yang dipusatkan pada keadaan klien (clien centered methode). Metode ini sering disebut non directive (tidak mengarahkan) dalam metode ini terdapat dasar pandangan bahwa klien sebagai makhluk yang bulat yang mempunyai kemampuan berkembang sendiri.

d. Directive Counseling. Merupakan bentuk psikoterapi yang paling sederhana, karena konselor secara langsung memberikan jawaban terhadap problem yang oleh klien disadari menjadi sumber kecemasannya.

e. Metode Psychoanalysis

Adalah juga terkenal dalam konseling yang mula-mula diciptakan oleh Sigmund Freud. Metode ini berpangkal pada pandangan bahwa semua manusia itu bila mana pikiran dan perasaannya tertekan oleh kesadaran dan perasaan atau motifmotif tertekan tersebut masih aktif mempengaruhi segala tingkah lakunya meskipun mengendap di dalam alam ketidaksadaran (dus-s) yang disebut "vedrogen complexion". ${ }^{27}$ Pada dasarnya materi bimbingan agama tergantung pada tujuan yang hendak dicapai. Adapun pengertian materi bimbingan agama adalah seluruh ajaran Islam secara kaffah dan tidak di penggal-penggal atau sepotong-potong, yaitu yang telah tertuang dalam al-Qur'an dan dijabarkan nabi dalam hadits. Sedangkan dalam pengembangan mencakup seluruh kultur Islam yang murni bersumber dari kedua pokok ajaran Islam tersebut. Adapun materi bimbingan agama antara lain:

\section{Materi aqidah (tauhid atau keimanan)}

Adalah sebagai sistem kepercayaan yang pokok pangkal atas kepercayaan dan keyakinan yang sesungguh-sungguhnya akan ke

\footnotetext{
${ }^{27}$ Ibid.
} 
Esa-an Allah SWT. $^{28}$ Aqidah merupakan ajaran pokok Islam yang terkait dengan keyakinan ini terangkum dalam rukun imanm yaitu iman kepada Allah, malaikat, kitab suci, iman kepada rasul, iman kepada hari akhir, dan iman kepada qadha' dan Qodar. Aqidah ini merupakan ruh bagi setiaip orang dengan berpegang teguh kepadaNya maka manusia akan hidup dalam keadaan yang baik dan mengembirakan, tetapi bila manusia meninggalkannya maka matilah semangat kerohaniannya. Aqidah adalah sumber dari rasa kasih sayang yang terpuji, aqidah merupakan tempa teranamnya perasaan- perasaan yang indah dan lurus, juga sebagai tempat tumbuhnya akhlak yang mulia dan utama. ${ }^{29}$

\section{Materi Syari'ah}

Syari'ah berarti tatanan, perundang-undangan atau hukum yaitu tata aturan yang mengatur pola hubungan manusia dengan Allah secara vertical, dan hubungan manusia sesamanya secara horizontal. Kaidah syari'a'h yang mengatur hubungan manusia dengan Tuhan disebut ibadah, sedang kaidah syari'at yang secara khusus mengatur pola horizontal dengan sesamanya disebut muamalah. Dengan demikian syari'at meliputi ibadah dan muamalah.

\section{Materi Akhlakul Karimah}

Akhlak adalah sikap yang tertanam dalam jiwa daripadanya timbul perbuatan yang mudah tanpa memerlukan pertimbangan pikiran. Akhlak Islam ialah suatu sikap mental dan tingkah laku perbuatan yang luhur, mempunyai hubungan dengan Dzat yang Maha Kuasa. Akhlak Islam adalah produk dari keyakinan atas ke-Esa- an Tuhan. ${ }^{30}$ Menurut ajaran Islam, bimbingan akhlakul

\footnotetext{
${ }^{28}$ M. Aminuddin Sanwar, Pengantar Ilmu Dakwah (Semarang: Fakultas Dakwah IAIN Walisongo, 1986), 75.

${ }^{29}$ Sayyid Sabiq, Fiqih Sunnah Jilid 4 (Jakarta: Pena Pundi Aksara, 2002), 21.

${ }^{30}$ A Razak, The General Characteristics of the Indonesian Press, Media Asia 13 (4), 1986, $218-225$
} 
karimah adalah faktor penting dalam membina suatu umat, dan membangun suatu bangsa oleh karena itu bimbingan akhlak harus ditanamkan sejak dini. Bimbingan akhlak ini sangat penting karena menyangkut sikap dan perilaku seyognya dilaksanakan oleh seorang muslim dalam kehidupan sehari-hari, baik personal (pribadi) maupun sosial. Yang termasuk akhlak di sini adalah seperti perbuatan baik kepada orang tua, saling hormat-menghormati, bersilaturrahmi, saling menasehati, dan sebagainya.

\section{Pengamen dan Persoaalan sosial}

Manusia diciptakan Allah SWT sebagai makhluk yang sempurna, terdiri dari unsur jasmani dan rohani. Kedua unsur ini mempunyai kebutuhan yang harus diperoleh perhatian yang seimbang karena dengan perhatian dan pemeliharaan keduanya, manusia dapat mencapai kebahagiaan dan ketenteraman serta akan menjadikan dirinya bertingkah laku yang baik terhadap orang lain. Namun dalam kenyataannya dengan adanya kemajuan teknologi yang semakin canggih, manusia ingin mengejar kebutuhan yang bersifat materi, mereka lupa akan kebutuhan rohani, seakan-akan timbul anggapan bahwa materi adalah segala-galanya akan dapat terselesaikan. Kebahagiaan yang hendak dicapai akan semakin jauh karena hidup semakin sulit dan beban jiwa semakin berat.

Dengan motivasi itulah mereka akan melakukan tindakan yang telah dilarang oleh undang-undang. Sifat manusia sekarang yang selalu ingin hidup mewah tapi tidak mau bekerja keras maka, manusia akan melakukan apa saja untuk kesenangan dirinya. Setiap manusia yang hidup di dunia ini pasti mengharapkan dirinya hidup dengan bahagia dan sejahtera. Anggota Kipas yang kurang mendapatkan perhatian dan kasih sayang dari orang tua itu merasa tidak aman, merasa kehilangan tempat berlindung dan tempat berpijak. Dikemudian hari mereka akan mengembangkan reaksi kompensatoris dalam bentuk dendam dan sikap bermusuhan terhadap dunia luar. Anggota Kipas mulai "menghilang" dari rumah, lebih suka bergelandangan dan mencari kesenangan hidup yang imaginer di tempat-tempat lain. Dia mulai berbohong dan 
mencari perhatian dan mengganggu orangtuanya. Mereka bahkan mulai mengembangkan reaksi kompensatoris negatif untuk mendapatkan kenikmatan dan kepuasan hidup dengan melakukan perbuatan kriminal.

Adapun para pengamen jalanan itu salah satunya disebabkan karena rumah tangga yang berantakan, tidak adanya pekerjaan, dan bahkan karena hoby, keterbatasan ekonomi, maka dari itu mereka mempunyai peluang untuk melakukan kejahatan dengan adanya pengaruh lingkungan yang sangat mendukung. Hal itu mengakibatkan permasalahan bagi mereka, karena masa yang mereka lalui merupakan masa yang memerlukan pendamping dan figur dalam hidupnya, akhirnya mereka membentuk komunitas sendiri dan hidup dalam peraturan sendiri, mereka hanya mempunyai tekad untuk hidup dan mencari kepuasan dalam hidup ini. Diantaranya mereka menjadi pengamen jalanan mereka yang hidup di jalanan tentunya mempunyai kehidupan yang layak manusia pada umumnya. Kalau kita analisa, pengamen jalanan secara mayoritas merupakan orang-orang yang hidup dalam komunitas Kipas, mereka berjuang mencari uang untuk menghidupi keluarga untuk kebutuhan sehari-hari karena hidup memerlukan makan, sandang dan papan. Pengamen jalanan merupakan generasi penerus bangsa sama dengan yang lainnya, sebagai generasi penerus bangsa, mereka memerlukan pembinaan dan bimbingan supaya mereka menjadi manusia yang bertanggungjawab, tangguh, dan berbudi luhur. Agar tidak terjadi tindakan kriminal adanya pengaruh lingkungan maka para pengamen membentuk suatu komunitas, yaitu Kipas (Kiprah Pengamen Semarang). Tetapi yang menjadi permasalahan adalah bagaimana menerapkan proses bimbingan yang baik dan berkelanjutan, agar dapat mereka terima dengan mudah dan tepat sasaran. Hal itu penulis kemukakan karena membimbing para pengamen jalanan tidak sama dengan membimbing orang pada umumnya. Membimbing pengamen jalanan diperlukan kesabaran dan keikhlasan selama yang kita ketahui, pengamen jalanan merupakan orang yang terbiasa hidup dalam kondisi dan situasi yang serba bebas tanpa adanya ikatan, 
mereka sering berbuat sesuatu dengan sesuka hati. Padahal kita tahu bahwa kehidupan manusia diatur oleh macam-macam aturan agar tidak timbul kekacauan dan kesewenangan tingkah laku. Perilaku yang diperlihatkan seseorang dibatasi oleh macammacam tata cara agar dapat harmonis dalam lingkungannya dan tidak menimbulkan masalah pada dirinya sendiri maupun lingkungan mereka tinggal. Dalam agama Islam disinilah konsepkonsep positif berperan, tentang apa sesungguhnya hidup dan dimana arah tujuannya. Oleh karena itu manusia menjaga dirinya dari perbuatan-perbuatan yang dilarang oleh Allah SWT dan membentengi dirinya dengan mempertebal keimanan. Apabila keimanan atau akidah telah ditanamkan dalam dada, maka manusia akan mudah mengerti akan dunia kehidupan di dunia dan akhirat nantinya. Dan sudah sewajarnya bagi setiap orang yang beriman menjalankan kewajiban-kewajiban yang ubudiyyah maupun yang muamalah sebagai bekal untuk kehidupan di akhirat nanti. Dan setiap manusia harus bertaqwa kepada Allah serta menjalankan segala apa yang diperintahkan dan menjauhi apa yang dilarangnya. Tata cara kehidupan mengandung arti bahwa tingkah laku seseorang diatur oleh keharusan-keharusan untuk memperlihatkan sesuatu tingkah laku dan batas-batas yang memberi petunjuk apa yang tidak boleh dan tidak baik dilakukan. Jadi seseorang diharapkan mengetahui dan dapat diperlihatkan suatu tingkah laku sesuai dengan keharusan dan batas-batas yang digariskan dalam lingkungan hidupnya. Para anggota Kipas yang sehari-harinya terbiasa dengan kebebasan dalam pergaulan akibat dari kurangnya kontrol sosial, sehingga tidak sedikit dari para pengamen yang terjerumus dalam berbagai perilaku yang menyimpang dari norma masyarakat dan bertentangan nilai-nilai agama, sehingga perlu adanya suatu bimbingan agama dan pengarahan yang dapat memperbaiki sikap dan perilaku mereka. Bimbingan agama dalam rangka membangun sikap religius, tentu akan menyangkut beberapa unsur dalam pelaksanaannya. Karena dalam bimbingan itu sendiri terdiri dari beberapa unsur, antara lain, para pengamen jalanan sebagai orang yang dibimbing, petugas 
pembimbing, dan metode bimbingan. Para pengamen jalanan yang tergabung dalam komunitas Kipas (Kiprah Pengamen Semarang) tentunya mempunyai peraturan atau tata tertib yang harus dipatuhi dan dilaksanakan oleh semua anggotanya sebagai konsekuensi logis dalam berorganisasi, termasuk mengikuti kegiatan bimbingan agama bagi para pengamen yang ada di komunitas Kipas telah membuat program dan jadwal kegiatan bimbingan agama yang dilaksanakan sebulan satu kali, yaitu hari Jum'at pertama adapun waktu pelaksanaannya setelah habis sholat Jum'at bertempat di kompleks TBRS (Taman Budaya Raden Saleh).

\section{Studi Kasus: Bimbingan Agama Terhadap Para Pengamen Jalanan}

Krisis ekonomi yang terjadi mulai tahun 1997 sampai sekarang, mengakibatkan bertambahnya serentetan krisis yang melanda Indonesia. Krisis yang terjadi di negara kita tercinta ini mengakibatkan daya beli masyarakat menjadi merosot tajam harga barang dan bahan pokok menjadi melambung, kemampuan produksi pabrik semakin menurun diakibatkan bahan-bahan yang dibutuhkan untuk memproduksi terutama menimpa pada pabrikpabrik kecil, hal itu menambah banyaknya hitungan pekerja yang di PHK (Pemutusan Hubungan Kerja) yang terjadi di berbagai perusahaan dan sektor industri yang pada akhirnya dengan bertambahnya masyarakat pengangguran di negara Indonesia, maka jumlah masyarakat miskin semakin bertambah. Kemiskinan yang semakin membumi di negara kita tercinta ini ternyata menimbulkan berbagai masalah sosial. Salah satu masalah sosial yang paling menonjol adalah kenyataan bahwa banyak anak yang tidak mempunyai kesempatan untuk mengenyam pendidikan formal dan tidak kurang anak-anak yang sedang menjalani pendidikan sekolah harus rela meninggalkan bangku sekolahnya dikarenakan keberadaan ekonomi keluarga yang tidak memungkinkan lagi anak itu sekolah. Biasanya banyak diantara mereka turun ke jalanan untuk mengadu nasib dengan anak-anak 
yang lainnya. Mereka menjadi gelandangan, peminta-minta, penyemir sepatu, pengamen dan lain sebagainya, yang tidak jarang mereka mendapat predikat "sampah masyarakat". Perilaku pengamen jalanan yang tergabung dalam komunitas Kipas pada umumnya berhubungan erat dengan kehidupan yang ada di jalanan. Jadi mereka akan sangat mudah untuk dipengaruhi atau terpengaruh oleh lingkungan yang ada disekitarnya. Dalam kondisi seperti ini mereka berusaha mencari identitas diri. Sedangkan dalam upaya mencari identitas dirinya, mereka kerap sekali dihadapkan pada persoalan-persoalan kesenjangan norma sosial antara norma yang diajarkan oleh orang tua dan norma yang berlaku di masyarakat secara umum. Hal itu mengakibatkan gejolak jiwa para pengamen jalanan yang tergabung dalam komunitas Kipas sehingga memicu terjadinya tindakan kriminal atau pemberontakan-pemberontakan oleh anak. Dalam melakukan bimbingan keagamaan tentunya ada faktor yang menjadi penunjang dan penghambat dalam proses pelaksanaannya. Sebagaimana kita ketahui bahwa ada enam faktor yang mempengaruhi sukses atau tidaknya sebuah proses bimbingan, diantaranya intensitas atau seringnya bimbingan diberikan kepada pengamen jalanan, adanya kesadaran pada diri setiap pengamen yang menjadi obyek bimbingan.

Sedangkan faktor yang menghambat terhadap proses bimbingan keagamaan pada Kipas adalah kurangnya minat dan kesadaran dari pengamen itu sendiri, padahal bimbingan akan dapat berjalan dengan baik apabila para pengamen tersebut mempunyai kesadaran untuk memperbaiki hidupnya. Kemudian komunitas Kipas (Kiprah Pengamen Semarang) masih mempunyai kekurangan dalam sarana dan prasarana. Salah satu alat yang dapat menunjang keberhasilan komunitas Kipas adalah dengan bimbingan keagamaan seperti ceramah-ceramah, dan penunjang yang lainnya yaitu seperti buku-buku bacaan guna menambah wawasan dan pengetahuan bagi para pengamen. Dalam membina anggota Kipas tidak hanya cukup dengan peranan lembaga-lembaga yang berada diluar pemerintah, akan tetapi pemerintah sangat 
dibutuhkan karena pengamen juga merupakan generasi bangsa dimasa depan. Kalau pemerintah tidak memperhatikan para pengamen maka bagaimana nasib bangsa kita. Jadi untuk mencapai hasil yang maksimal dalam menjalankan proses pembinaan kepada anggota Kipas, peranan dan sumbangan berbagai lapisan masyarakat dan berbagai unsur sangat diperlukan, baik itu berupa tenaga, pikiran, materi ataupun kebijakan yang dapat menjadikan terjadinya proses pembinaan yang baik dan membuahkan hasil yang maksimal.

Setelah peneliti mengkaji dan memahami tentang pelaksanaan bimbingan keagamaan dan faktor-faktor yang mendukung dan menghambat dalam proses bimbingan keagamaan yang diberikan kepada organisasi Kipas, maka selanjutnya peneliti akan menganalisa hasil bimbingan keagamaanya. Adapun jalannya bimbingan di komunitas Kipas yang diadakan setiap sebulan sekali pada hari Jum'at pertama yaitu dengan metode ceramah yang disertai dengan sesi tanya jawab dan rata-rata diikuti tidak kurang dari lima puluhan pengamen dengan beragam usia. Setelah peneliti mengamati proses bimbingan yang dilaksanakan oleh komunitas Kipas penulis dapat menyimpulkan beberapa hal yang berhubungan dengan fokus penelitian yang peneliti lakukan. Para pengamen yang mengikuti proses bimbingan keagamaan secara biologis dapat digolongan menjadi tiga golongan yaitu anak-anak, remaja dan usia dewasa. Sedangkan menurut permasalahan yang mereka alami yang kemudian bisa digolongan dalam ranah psikologis yaitu meliputi kesulitan ekonomi, penyaluran hobi dan juga sebagai pelarian dari suatu permasalahan (dalam kasus ini kebanyakan muncul dari keluarga yang buruk, broken home). Pada dasarnya pengamen tidaklah jauh beda dengan manusia lainnya, mereka juga merupakan makhluk sosial dan religius yang sempurna, terdiri dari unsur jasmani dan rohani. Kedua unsur ini mempunyai kebutuhan yang harus diperoleh perhatian yang seimbang karena dengan perhatian dan pemeliharaan keduanya, manusia dapat mencapai kebahagiaan dan ketenteraman serta akan 
menjadikan dirinya bertingkah laku yang baik terhadap orang lain. Namun dalam kenyataannya dengan adanya kemajuan teknologi yang semakin canggih, manusia dihadapkan pada kebutuhan yang bersifat materi, dan mereka seolah melupakan dan mengesampingkan akan kebutuhan rohani, seakan-akan timbul anggapan bahwa materi adalah segala-galanya akan dapat terselesaikan. Kebahagiaan yang hendak di capai akan semakin jauh karena hidup semakin sulit dan beban jiwa semakin berat. Dengan motivasi itulah mereka akan melakukan tindakan yang telah dilarang oleh undang-undang. Sifat manusia sekarang yang selalu ingin hidup mewah tapi tidak mau bekerja keras maka, manusia akan melakukan apa saja untuk kesenangan dirinya. Setiap manusia yang hidup di dunia ini pasti mengharapkan dirinya hidup dengan bahagia dan sejahtera.

Dari fenomena-fenomena di atas kemudian peneliti berkesimpulan bahwa permasalahan atau problem yang kebanyakan dihadapi mereka yaitu kesulitan ekonomi, penyaluran bakat atau menjalankan hoby dan sebagai pelarian dari masalah keluarga (broken home). Dalam pelaksanaan bimbingan keagamaan pada komunitas Kipas, mereka menitik beratkan pada penanaman nilainilai aqidah, yang seperti kita ketahui bersama bahwa aqidah merupakan ujung tombak manusia untuk melangkah pada proses perbaikan perilaku yang lebih baik. Setelah peneliti mengamati dan mengetahui tentang sikap dan perilaku para anggota Kipas yang berada di bawah bimbingan, maka peneliti dapat mengambil kesimpulan bahwa pembinaan masalah akhlak sudah berjalan dengan baik dan membuahkan hasil yang cukup signifikan bisa membawa perubahan perilaku para pengamen, karena perilaku dan sikap anggota Kipas itu baik, baik terhadap dirinya sendiri maupun terhadap orang lain, dan sudah tertanam dalam jiwanya sikap saling membutuhkan antara satu dengan yang lainnya yang pada akhirnya mereka bisa saling tolong baik dengan temannya sendiri maupun dengan orang lain. Keberhasilan yang dicapai itu merupakan hasil jerih payah pihak yang terkait dengan pembinaan anggota Kipas terutama pihak pembimbing yang dengan tekun dan 
teliti memberikan bimbingan dan pengarahan kepada mereka dalam hal-hal yang positif yang dapat bermanfaat bagi kehidupan mereka di masa sekarang dan di masa yang akan datang.

\section{Penutup}

Orang-orang yang ada di jalanan yang pekerjaannya mengamen atau menyanyi di dalam bus-bus kota sering mendapatkan kecaman dari masyarakat yang bersifat negatif dan menjatuhkan martabat mereka. Selain itu, kehidupannya terganggu oleh orang-orang yang berbuat kehendak sendiri dalam arti suka bertindak kriminal. Padahal orang-orang yang bekerja sebagai pengamen itu butuh makan dalam menjalani kehidupannya, dengan rasa saling menolong serta menghargai sesama teman, maka orang-orang yang bekerja sebagai pengamen membentuk sebuah kelompok-kelompok kecil di mana mereka saling menjaga satu dengan yang lainnya. Berdasarkan uraian tersebut dan dari penelitian yang penulis lakukan telah diadakan pembahasan sepenuhnya, maka penulis dapat mengambil kesimpulan sebagai berikut: Kemajuan zaman menjadikan banyak orang yang termarginalkan, kemudian orang-orang tersebut terpaksa menjadi pengamen untuk memenuhi kebutuhan hidupnya dan keluarganya. Tidak jarang orang-orang yang ada di jalanan yang pekerjaannya sebagai pengamen atau menyanyi di dalam bus-bus kota sering mendapatkan kecaman dan perlakuan yang kurang menyenangkan dari masyarakat memandang negatif dan menjatuhkan martabat mereka. Dalam kondisi seperti ini tidak menutup kemungkinan bagi orang-orang yang tergabung di dalam organisasi Kipas melakukan kriminalitas. Semakin beratnya tantangan untuk memenuhi kebutuhan hidupnya, ditengah-tengah interaksi dengan lingkungan mereka masing-masing, Bagi sebagian orang dapat memicu untuk bertindak kriminal. Berdasarkan hasil penelitian yang dilakukan, kegiatan bimbingan agama yang diadakan komunitas Kipas, ternyata berperan penting dalam upaya untuk menanggulangi tindak kriminal dan upaya meningkatkan 
kepribadian para pengamen jalanan yang ada di Komunitas Kipas. Hal ini dapat kita lihat dari keaktifan para pengamen jalanan dalam mengikuti bimbingan dan pengarahan pada komunitas Kipas yang dilaksanakan setiap bulannya. Bimbingan tersebut diharapkan dapat meminimalisir dan memperbaiki sikap dan perilaku mereka sehari-hari yang cenderung hidup bebas, seperti halnya melaksanakan ibadah sholat wajib lima waktu, sunnah, puasa di bulan ramadhan, membaca al-Qur'an, dan melakukan hal-hal yang berkaitan dengan kepedulian sosial, seperti menolong orang yang kena musibah, menjenguk orang yang sedang sakit dan lain sebagainya. Sikap keberagaman komunitas Kipas yang ada di Semarang menunjukkan perkembangan yang cukup baik, walaupun tidak semua sikap keberagamaan dalam materi bimbingan dapat dilaksanakan sepenuhnya sesuai dengan ajaran dan syari'at Islam. Hal ini karena lingkungan sekitar ikut mempengaruhi terhadap keberagamaan mereka. 


\section{DAFTAR PUSTAKA}

Amin. Mengatasi Krisis Setengah Baya, Bandung: Sinar Baru, 1997.

Arifin. Pokok-pokok Pikiran tentang Bimbingan dan Penyuluhan Agama, Jakarta, Bulan Bintang, t.th.

Ashiddieqy, Hasbi. Al Islam Jilid 1, Jakarta: Bulan Bintang, 1970.

Azizy, Qodri. Pendidikan Agama Untuk Membangun Etika Sosial, Semarang: Aneka Ilmu, 2002.

Departemen Pendidikan dan Kebudayaan. Kamus Besar Bahasa Indonesia, Jakarta: Balai Pustaka, 1997.

Epistein, Robert. Memotivasi, Yogyakarta: Pustaka, 2004.

Fajri, EM Zul., dan Ratu Aprilia Senja. Kamus Lengkap Bahasa Indonesia Edisi Revisi, Cet. 2; Semarang: Difa Publishers, 2007.

Fajri, Em Zul. Kamus Lengkap Bahasa Indonesia, Jakarta: Difa Publiser, 2007.

Faqih, Ainur Rahim. Bimbingan Konseling Islam, Yogyakarta, UII Press, 2001.

Handoko, Martin. Motivasi Daya Penggerak, Yogyakarta: Kanisius, 1992.

Kartono, Kartini. Psikologi Anak; Psikologi Perkembangan, Bandung, Mandar Maju, 1995. . Patologi Sosial Jilid I, Jakarta: Rajawali Pers, 2011.

Kuper, Adam., dan Jessica Kuper. Ensiklopedi Ilmu-ilmu Sosial, Edisi 2, Jakarta, PT. Grafindo Persada, 2000.

Odea, Thomas F. Sosiologi Agama; Suatu Pengenalan Awal, Jakarta: Rajawali Press, 1985.

Prayitno, H., dan Erman Amti. Dasar-dasar Bimbingan dan Konseling, Jakarta: PT. Rineka Cipta, 1999. 
Razak, A. The General Characteristics of the Indonesian Press, Media Asia 13 (4), 1986.

Sabiq, Sayyid. Fiqih Sunnah Jilid 4, Jakarta: Pena Pundi Aksara, 2002.

Sanwar, M. Aminuddin. Pengantar Ilmu Dakwah, Semarang: Fakultas Dakwah IAIN Walisongo, 1986.

Siswanto. Pengantar Manejemen, Jakarta: Bumi Aksara, 2005.

Soekadijo, Reg., Antropologi Jilid 2, Jakarta: tp, 1985.

Syani, Abdul. Sosiologi Kriminalitas, Bandung: CV. Remaja Karya, 1987.

Zaini, Syahminan. Wawasan Al-Qur'an Tentang Pembangunan Manusia Seutubnya, Malang: Kalam Mulia, 1986. 